\title{
Communicative Language Teaching Strategies for German as a Foreign Language in Uganda
}

\author{
Samuel Sekiziyivu \\ Department of Humanities and Language Education, School of Education, College of Education and External Studies, \\ Makerere University, Uganda \\ Christopher B. Mugimu \\ Department of Foundations and Curriculum Studies, School of Education, College of Education and External Studies, \\ Makerere University, Uganda
}

\begin{abstract}
The communicative language teaching (CLT) approach emphasizes the change in the role of the teacher from a transmitter of knowledge to a facilitator of language learning. Teachers must therefore, develop and utilize teaching strategies that enable learners to freely interact in a classroom environment to enhance the required communicative competences. However, in the Ugandan context where the curriculum is examination-driven, teacher competence is judged on the basis of students' excellence in the final examinations. As such, teachers tend to focus on producing better grades, thereby neglecting learners' acquisition of vital communicative competences. This paper spells out the teaching strategies teachers of German use to create a supportive environment for communicative language teaching and learning. A cross sectional survey research design was used in the study. Questionnaires, observations, and semi-structured interviews were used to gather data on teachers' experiences regarding the teaching strategies used to support CLT approach. Findings revealed that the teaching strategies utilised by the teachers of German had very little bearing on the CLT approach. For instance, the classroom environment did not encourage free interaction among learners as required by the CLT approach. It was recommended that teachers be introduced to teaching strategies that are relevant to the CLT approach during their pre-and in-service training.
\end{abstract}

Index Terms - communicative language teaching strategies, communicative competences, German, teachinglearning environment

\section{INTRODUCTION}

Communicative Language Teaching (CLT) is based on the concept of communicative competence by which learners are expected to possess the ability to understand a language and be able to use it for the purposes of effective communication. Ultimately, in order for learners to learn how a language is used in real-life situations, the teachinglearning environment has to be organized in such a way that it closely reflects, as much as possible, the real-life situation outside the classroom. The teaching-learning environment in CLT, therefore, entails the choice of teaching strategies that would engage learners in active language production within the classroom. As such, teaching strategies focus on tasks and activities that should reflect the actual use of language in real-life situations. Teaching strategies may include tasks that encourage learners' exchange of ideas through free interaction, such as group work, and pair work. The choice of teaching strategies in the CLT approach is based on the communicative competence model put forward by Canale and Swain (1980) and Canale (1983) as well as acknowledged by several scholars such as Irvine-Niakaris (1997) and Sekiziyivu and Mugimu (2015).

According to Canale and Swain (1980) the model emphasizes the following competencies:

- Linguistic/grammatical competence

- Sociolinguistic competence

- Discourse competence

- Strategic competence

Canale (1983, pp. 6-9) defines the four communicative competences as follows; Linguistic/grammatical competence refers to the extent to which mastery of the language code has occurred, including vocabulary knowledge, word formation, syntax, pronunciation, spelling and linguistic semantics. Sociolinguistic competence refers to mastery of the socio-cultural rules of language use and rules of discourse; [i.e.] the extent to which utterances are produced and understood appropriately... depending on contextual factors [such as], the status of participants, the purpose of the communication and the conventions associated with the context. Discourse competence refers to mastery of "how to combine grammatical forms and meanings to achieve a unified spoken or written text", [which is] suitable to the genre; including use of cohesion and coherence. Strategic competence refers to mastery of verbal and non-verbal communication strategies employed during the breakdown in communication or when [an individual] lacks any of the competencies to communicate effectively. 
Thus, the concept of communicative competence brings out the importance of such fundamental aspects of language use which include; knowledge of language forms (grammar), appropriate use of language, given the social contexts, use of cohesion and coherence devices, and knowledge of verbal and non-verbal communication strategies to compensate for any language deficiencies. The goal of teaching strategies for a language, therefore, has to focus on the achievement of these articulated communicative competencies. In this regard, different scholars have come up with theories outlining the underlying features of the CLT approach.

For instance, D. Nunan (1991) in Butler (2005, p. 424) proposed the theoretical framework of CLT could be characterized as:

- a focus on communication through interaction;

- the use of authentic instructional materials;

- a focus on the learning process as well as the language itself;

- belief that learners' own experiences can contribute to learning; and

- A linkage between language learning in the classroom and real-life activities.

Therefore, by drawing on Nunan's theoretical framework, the teacher can operationalize and develop teaching strategies that address vital communicative aspects of language use. We find this framework ideal in enhancing learners' communicative competences if the teacher is able to integrate and apply all the mentioned characteristics into their teaching strategies. As such, this framework should be part and parcel of the training and support for teachers of language. Failure to give teachers this needed training and support would result into difficulties in assisting learners acquire the desired language communicative competences.

Indeed, Widdowson (1972) points out that the root of the problem to the learners' deficiency in their ability to actually use the language lies in the teaching strategy itself. Teaching strategies are extremely vital in learners' acquisition of communicative competences. This is not surprising because the way learners are taught to use the language, is the very way they would use it even in real-life situations. Teachers therefore have to take into consideration the purpose for language learning and employ appropriate teaching strategies that would easily help them achieve the desired objective. The role of the teacher and learner is vital and calls for serious attention.

What are the roles of the teacher and learner in a communicative language classroom?

As observed by Snow (1996) learners learn effectively about language when they take part actively in the communication of the language rather than only passively accepting what the teacher said. As such, Littlewood (2014, p. 352) argue that

To implement these new practical demands teachers have had to make major changes and attitudes - to change their conception of their own role from that of a transmitter of knowledge to that of a multi-role educator, and to change their conception of language learning from one based on language acquisition to one based on the holistic development of competence.

It is therefore expected that in an ideal communicative classroom, learners are not mere recipients of the language produced by the teacher, but they are active participants in the actual language production. This further implies that the teacher is no longer a mere instructor but a facilitator in the process of language production. Hence, there is a paradigm shift in terms of the changing teacher's role within a communicative classroom.

This is also in line with Jin, Singh, and Li $(2005$, p. 7) who suggests that "the major task of the teacher is to create a learning environment or a setting for learners to acquire language by using it through activities in class." This implies that the teacher has to organise such activities that would engage learners into active free interaction with one another and with the teacher, thus, avoiding the over emphasis on teaching grammatical structures while ignoring free communication and interaction. This remains to be a challenge in the context of large classes and the realities of creating supportive environments for ensuring learners' active communication in such situations is questionable.

Furthermore, Widdowson (1978) points out that an overemphasis on grammar would prevent the learners from developing the basic communicative competence. This challenges the creativity and innovation of the teachers in terms of utilizing a variety of teaching strategies.

Richards and Rodgers (1987, p. 76) noted that;

The range of exercise types and activities compatible with a communicative competence approach is unlimited, provided that such exercises enable learners to attain the communicative objectives of the curriculum, engage learners in communication, and require the use of such communicative processes as information sharing, negotiation of meaning and interaction. Classroom activities are often designed to focus on completing tasks that are mediated through language or involve negotiation of information and information sharing.

It is surprising that though there are unlimited exercise types and activities as indicated by Richards et. al, majority of teachers are unable to exercise their creativity in utilizing appropriate teaching strategies - i.e. tasks and activities. Indeed, many teachers fail to integrate the four language skills i.e. listening, speaking, reading and writing as required. Yet, teachers should play a significant role in facilitating language learning in meaningful ways (Sreehari, 2012).

In fact, D. Nunan (1989) cited in Sekiziyivu and Mugimu (2015, p. 45) notes that teachers should, while designing activities, consider all the skills, co-jointly as they interact with each other in natural behaviour, for in real-life as in the classroom, most tasks of any complexity involve more than one macro skill. This stresses the importance of integrating the four language skills as opposed to teaching each of the skills separately and that communicative language 
classrooms have to involve interactive activities that reflect natural language use. There is, therefore, a need for a clear understanding of how skills could be possibly integrated in the case of Uganda, where the learning environment is characterized by lack of authentic instructional materials, existence of large classes, and incidence of German being rare in use (Mugimu \& Sekiziyivu, 2016). It is critical to understand whether the language teaching-learning environment allows for the creation of teaching strategies enriched with interactive activities.

However, the need to create supportive teaching-learning environments for enhancing the acquisition of communicative competences in classrooms cannot be underscored. Supportive teaching-learning environments as observed by Wesche and Skehan (2005, p. 208) should generally feature:

- Activities that require frequent interaction among learners or with other interlocutors to exchange information and solve problems.

- Use of authentic (non-pedagogic) texts and communication activities linked to "real world" contexts, often emphasizing links across written and spoken modes and channels.

- Learner-centred approaches which take into account learners' backgrounds, language needs, and goals, and generally allow learners some creativity and role in instructional decisions.

Similarly, Liao (2011, pp. 19-20) suggests that the teacher sets up the communicative situations and motivates learners to participate in such activities as role plays, simulations, and social interactions in a near natural linguistic and social environment to learn to use language for communication. This is in agreement with Sreehari (2012) on types of learning activities and techniques to support CLT.

Figure 1 shows the relationship between communicative competence (CC), communicative language teaching (CLT), teaching strategies, and the teaching-learning environment. We conceptualise that CC is the determinant of both CLT and teaching strategies. Furthermore, the more competent the teacher is in matters of CLT the more likely he/she will be able to use appropriate teaching strategies that support learners' CC. However, all this will be influenced by the teaching-learning environment in which the teacher is operating, which may include; space, availability of authentic materials, examination-driven curriculum, etc. This is in line with Ahmad and Rao (2013, p. 202) finding that "impediments in applying the communicative approach are teacher training, students' hesitation in the use of target language, overcrowded classrooms, grammar-based examinations and the lack of appropriate materials". Coskun (2011) also concurs with Ahmad and Rao.

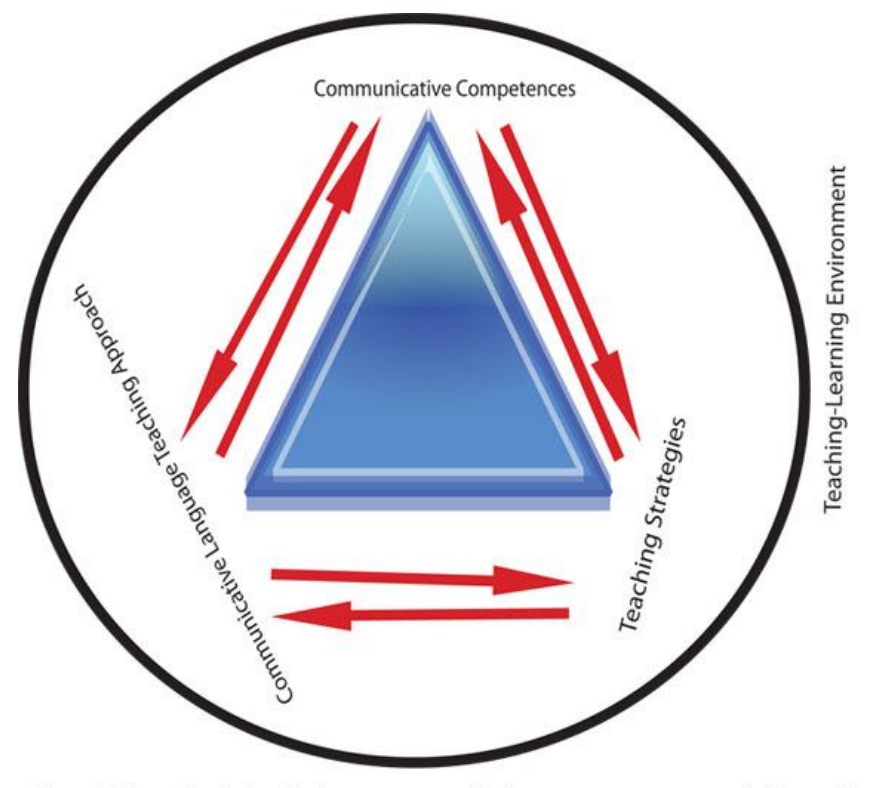

Figure 1. Shows the relationship between communicative competences, communicative teaching approach (CLT), Teaching Strategies, and Teaching-Learning Environrment

\section{PURPOSE}

The purpose of this study was to examine the teaching strategies utilized to support the CLT approach for enhancing learners' communicative competences in German.

\section{RESEARCH QUESTIONS}

1) What teaching strategies do teachers say they use in the classroom? 2) Do the teachers actually use the teaching strategies in the classroom? 
The study used blended methods that involved collection of both quantitative and qualitative data. We used a cross sectional survey research design in which questionnaires and interviews were utilised to collect data. The sample comprised of 20 secondary school teachers of German in Uganda. Items in the questionnaire and semi-structured interviews probed for the teaching strategies teachers use. The main teaching strategies probed for included: (1) Focus on meaning as opposed to grammar; (2) Learner-centred instruction; (3) Use of pair and small groups; (4) Use of authentic instructional materials; and (5) Integration of language skills.

In addition, classroom observations were carried out to establish whether teachers actually used the mentioned teaching strategies in a manner that was consistent with the CLT approach. To achieve this, the COLT observation scheme by Spada and Frohlich (1995) was adopted and modified to fit the objectives of this study.

\section{RESUlts \& ANALYSIS}

The qualitative data obtained from open-ended questionnaires was organised into common themes and sub-themes. The data collected from interviews was audio-recorded, transcribed, and then categorised according to common themes. The data generated from observations was video recorded and then analysed by comparing with data obtained from other sources. The quantitative data obtained from questionnaires were analyzed using SPSS to generate frequencies, percentages, and charts to gain a better understanding of teachers' experiences in utilizing appropriate teaching strategies that support the CLT approach.

This section presents findings gathered from teachers of German about the teaching strategies they use to support CLT approach. Teachers were probed and observed to understand the teaching strategies they used in the classroom. Figure 2 presents results of the comparison between the teaching strategies teachers say they used and what was observed. Interestingly, the findings in figure 2 show majority of teachers said they used the five highlighted teaching strategies. However, a discrepancy exists between what teaching strategies teachers say they used and what was actually observed by the researchers. For instance, the classroom observation revealed that although many teachers claimed they used these teaching strategies, fewer teachers actually used the strategies in their teaching. This was more evident with "learner-centered instruction", Use of pair and small groups" and "Use of authentic instructional materials". It seems that majority of teachers are actually aware of teacher strategies but surprisingly they are reluctant to use them in their teaching.

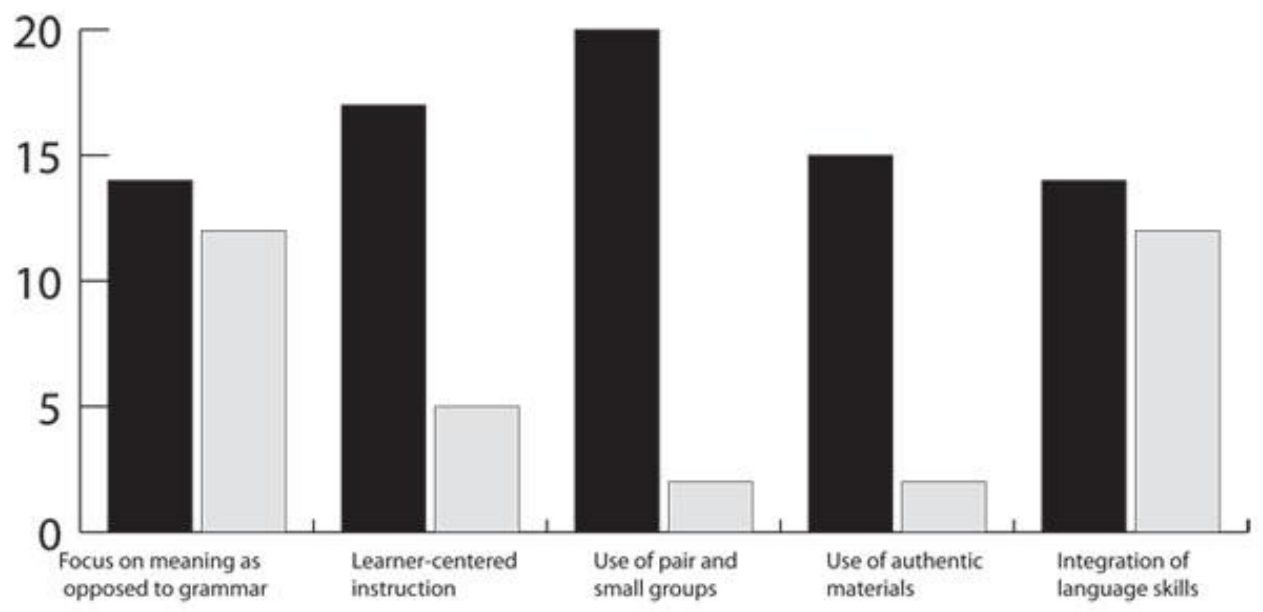

Figure 2 Shows a Comparision Between Teachers' Responses and Researchers' Classroom Observations

The question is; why are teachers not using the teaching strategies they say they use and know are necessary in enhancing the teaching-learning process? What constraints exist in the teaching-learning environment that hinders teachers' use of appropriate teaching strategies? The following section, presents teachers' interview responses on the five teaching strategies i.e. focus on meaning as opposed to grammar; learner-centred instruction; use of pair and small groups; use of authentic instructional materials and integration of language skills.

Focus on Meaning as Opposed to Grammar

Teachers' responses from interviews revealed that even though the teachers were aware of the need to focus more on meaning as opposed to grammar, majority of the teachers put more emphasis on the teaching of grammar. For example, one teacher noted that, "My lessons always focus on grammar because I feel that it is the basis for improvement in the language. However, I also try to focus on meaning because simply knowing the rules of grammar without putting sentences to use is meaningless. Therefore, I always encourage learners to speak and to write correct grammatical sentences and I always interrupt them in order to correct their grammar" TOG05

According to the above quotation, it is clear that the teacher attaches more importance to the teaching of grammar at the expense of learners' ability to freely communicate in a real-life situation. In fact the interruption this teacher makes 
in order to correct learners' grammatical mistakes is likely to be a hindrance to their free communication as well a demotivating factor to them.

Even other teachers had similar views about the importance of grammar in German language teaching. For instance, another teacher indicated that: "You cannot teach a foreign language without emphasizing its grammar. Learners have to grasp grammatical structures first and then learn the meaning and how they can be used in real-life situations" TOG12. This teacher seems to suggest that he/she could not be able to teach how to use grammar in a communicative context but would rather first lay down the rules of grammar, teach the structures and then, maybe, find a way of practising their use. This would also imply that the production of correct grammatical sentences was preferred to the fluency in the German language. This finding is also consistent with Raissi and Nor (2013, p. 882), observation that majority of teachers believe that equal attention should be given on fluency and accuracy.

Furthermore, another teacher observed that" learners make a lot of grammatical mistakes. So as a teacher, one has to strive to correct them. As such, a lot of time is spent on correcting learners' grammatical errors and pronunciations", TOG08. This implies that if so much time is spent on correcting grammatical mistakes, the teacher would have very little time left to engage learners in tasks that involve the use of the language in real-life situations, and therefore, the learners would be more conversant with the structure of the German language than its use in real-life communication.

\section{Learner-Centred Instruction}

In our interaction with teachers during the interviews many of them showed awareness of the importance of learnercentred instruction and were opposed to teacher-centred forms of instruction. For instance, a teacher noted that, " $A$ teacher-centred approach is mainly used with the teacher controlling and determining most of the content to be learned, while the learners follow and do what the teacher requires them to do. Which is not good" TOG01. Surprisingly, this is not consistent with the findings in figure 2, very few teachers actually use learner-centred instructions. What comes out clearly is that some teachers have misconceptions about the use of learner-centred instruction and meeting their roles as teachers. In this regard, one teacher shared that his/her major role was to deliver new information and to determine the content of the lesson as opposed to being a facilitator. This is reflected in the following quotation: "My main role in class is to deliver the new information and to determine what is to be learned." TOG02. Teachers' divergent views regarding their role seem to influence the teaching strategies they use in the classroom. Indeed, teacher's ability to play his/her facilitator role is critical in terms of offering the needed students' support and guidance. Liu (2015, p. 1172) argues that "students need occasional guidance to enable them set goals, make choices, or develop interest in various learning tasks and to be more actively involved in learning activities."

\section{Use of Pair and Small Groups}

The use of pair and small groups turned out to be the least used teaching strategy as reflected in figure 2. Teachers were probed about the "Use of pair and small groups" as a teaching strategy; however, although most of them knew its importance and effectiveness, they had a number of constraints that impacted on their use of the strategy. One of the teachers reported that,

"My classes rarely have pair and small group activities. We mostly use the teacher-fronted approach as well as working in plenary. This is so because of large numbers of learners which are difficult to organise, lack of teaching materials that support learners' work in groups, examination oriented teaching; examinations do not require learners to work in groups, therefore teaching has to orient the learners to the format of the examination" TOG05. This quotation clearly brings out some of the constraints of using pair and small group strategy in their classrooms such as large students' numbers, lack of authentic instructional materials and the examination orientated curriculum. This is consistent with Ngoc and Iwashita (2012, p. 27) who argue that in most cases examinations are designed to test only linguistic competences other than communicative competence. As such, in their attempt to satisfy the demands of parents and students, teachers tend to focus on what will appear on the final examination (Littlewood, 2014). Indeed, much as teachers may be aware of the merits of this kind of classroom organisation, the teaching-learning environment does not necessarily favour them in this respect. For instance, another teacher contends that; "Most of the class time is spent on listening to the teacher and the learners are carrying out tasks determined by the teacher. In most cases, tasks are carried out individually as opposed to working in pairs or small groups and that sometimes learners play roles, but not often. TOG03. Consequently, many teachers resort to teacher-centred instruction. This could discourage students' active engagement with learning activities and therefore undermine their motivation to learn and taking responsibility of their own learning (Liu, 2015; Qamar, 2016).

\section{Use of Authentic Instructional Materials}

As earlier observed in figure 2 very few teachers actually use authentic instructional materials in their teaching, even though many of them claimed to use them. Further interaction with the teachers during the interview also revealed that lack of authentic instructional materials was a serious constraint. This is reflected in the following quotation: "I try to use authentic instructional materials but I am limited by unavailability of these materials (i.e. audio-visual like tape recorders, and video) that could foster effective teaching and learning.... I only have a chalkboard and old textbooks". [TOG12]. This gap may actually contribute to teachers' failure to utilise authentic instructional materials in their teaching. Yet, the use of authentic materials serves as a chief aid in creating an authentic context in which learners can develop their communicative competences (Sreehari, 2012, p. 89).

Integration of Language Skills 
As regards the integration of language skills, teachers' responses were generally almost in agreement with the researcher observations. A large number of teachers actually tried to integrate the language skills during their teaching. Nonetheless, they were constrained by factors found within the teaching-learning environment. For example, a teacher noted that, I try to integrate the skills while teaching. However, since most of the materials do not present the four language skills in an integrated manner, I am therefore forced to teach them separately (TOG04). Another teacher also asserted that: "I try to integrate the skills during my lessons, but I am limited by unavailability of materials that could foster this. I would need audiovisual materials like tape recorders, and video to achieve this" TOG12.

The above quotations indicate that the teachers are actually aware of the need to integrate language skills. However, the teaching-learning environment is not favourable, which is in line with Drame (2013)'s assertion that lack of communicative materials considerably complicated the use of communicative methodology. For instance, lack of communicative instructional materials that are designed to enhance the integration of the four language skills, greatly hinders teachers' ability to use an integrated approach to German language teaching. Yet, as clearly illustrated in figure 1 the teaching-learning environment plays a significant role in determining the effectiveness of teaching strategies in CLT approach.

\section{DISCUSSION}

The purpose of the study was to examine teaching strategies utilised by teachers of German in Ugandan secondary schools to support the CLT approach. In this section, we discuss salient findings arising from this study based on the two research questions. The first question probed for what teaching strategies teachers say they use in the classroom? and the second question is "do teachers actually use the teaching strategies they say they use in the classroom? Results from the study have indicated that most teachers actually used the two teaching strategies i.e. "focus on meaning as opposed to grammar" and "integration of language skills." Regarding former, although many teachers acknowledge that focusing on meaning is very important, from our interactions with them it is clear that most of them give a lot of weight to grammar. As one teacher observed that, my lessons always focus on grammar because Ifeel that it is the basis for improvement in the language .... I always encourage learners to speak and to write correct grammatical sentences and I always interrupt them in order to correct their grammar [TOG05]. Another teacher concurred that you cannot teach a foreign language without emphasizing its grammar. Learners have to grasp grammatical structures first and then learn the meaning and how they can be used in real-life situations [TOG12]. Indeed, teachers normally select and teach content which emphasizes more of grammatical structures as opposed to meaning. This is in accordance with what Sato and Kleinsasser (1999) also observed in Japanese schools “...that grammar was presented without any context clues..." Yet, as D. Nunan (1991 ) in Butler (2005, p. 424) puts it, one of the theoretical bases of CLT is to provide a linkage between language learning in the classroom and real-life activities. Consequently, an over-emphasis on the explicit teaching of grammar will produce learners who cannot use the German language effectively for purposes of real-life communication (Richards \& Rodgers, 1987).

Findings of this study also revealed that many teachers try to integrate the language skills in their teaching. However, a number of limitations exist within the teaching-learning environments that have undermined their ability to do so. For instance, one of the teachers reported that, "most of the materials do not present the four language skills in an integrated manner... [we are]...forced to teach them separately" (TOG04). This is consistent with existing research that the teaching-learning environment in Uganda lacks authentic instructional materials which undermines the integration of language skills as needed (Mugimu \& Sekiziyivu, 2016 ).

Therefore, lack of authentic teaching materials that are designed to integrate the four language skills becomes a hindrance to the use of an integrated approach to German language teaching. Yet, as stated by D. Nunan (1989), in reallife, most tasks of any complexity involve more than one macro skill. As such, the importance of the integration of language skills in the teaching of communicative German language use, in order to mirror real-life language use cannot be overemphasized.This is so because, when learners complete their education, they will be expected to find, within the real-life context, opportunities for integrated use of the language skills. This implies that, first; the learners taught in such circumstances will have problems in using the language freely in real-life situations where the integration of skills is the norm. Second, the learners' creativity and motivation to practice or try out new things as far as language skills acquisition is concerned will also be undermined. Yet, the use of CLT approach has been found to increase motivation for learning (Ahmad \& Rao, 2013). In fact, Qamar (2016, p. 297) study revealed that "the seeds of proficient speaking are best sawed in a learner centred classroom where learners are allowed to assume greater control over their own learning." Thus, efforts must be made to ensure that supportive teaching-learning environments are created to enable the effective integration of language skills.

As earlier indicated, there was inconsistence in some cases between what teaching strategies teachers said they used and what they actually used in the classroom. Our classroom observations revealed that although many teachers claimed that they used certain teaching strategies, fewer teachers actually used them in their actual teaching. For instance, the teaching strategies, such as; "learner-centered instruction", Use of pair and small groups" and "Use of authentic instructional materials" are the most affected. Very few teachers used the three teaching strategies in their actual teaching, yet, they are aware of their importance as reflected in figure 2. For instance, investigations in all the language classes revealed that instruction of German was based on a very high degree of teacher-centeredness as opposed to a 
situation where learners initiate discourse the way it is supposed to be in real-life language use. In fact, Sreehari (2012, p. 90) contends that the type of activities that take place in the classroom can indicate the teaching-learning situation is teacher dominated or learner-centered. The fact that language learning was so controlled by the teacher, it was difficult for the learners to learn to use the language the way it is found in a natural real-life setting. This is contrary to the importance of classroom organisation in the communicative approach to teaching (D. Nunan, 1991). Similarly, teachers seem to know the benefits of organizing the class in groups, but they are not doing it. Yet, it is evident that use of pair and small groups empowers learners to take control of their own learning and is bound to produce learners who are able to communicate effectively in real-life situations. Regarding the use of authentic materials, teachers' awareness was high; however, the lack of these materials constrained teachers' use. Yet, as observed by Tomlinson (2012, p. 161) many researchers argue that explicit teaching of language through contrived examples and texts does not prepare them for the reality of language use outside the classroom. Therefore, it becomes very difficult to implement communicative language teaching in such a situation, where the teaching -learning environment was not so supportive.

\section{CONCLUSIONS}

The findings of this study provide concrete evidence on what teaching strategies teachers say they use and what they actually use. We found out that many teachers utilised both focus on meaning as opposed to grammar and integrated language skills. What comes out clearly is that proper acquisition of basic communicative competences as required by the CLT approach may require simultaneous emphasis on both grammar and meaning (Ngoc \& Iwashita, 2012). Otherwise, an overly focus on grammar does not work well, given that the two strategies are complementary to each other. Teachers should be encouraged to concurrently focus on both teaching strategies in their teaching. In the same vein, the integration of language skills is extremely vital and findings of this study revealed that many teachers actually make an effort to integrate language skills as needed. However, the teaching-learning environment is constrained in terms of scarce instructional materials especially integrated textbooks. Therefore, the Ministry of Education Science Technology and Sports should ensure that integrated German textbooks and other authentic instructional materials are made available in all schools. These authentic instructional materials could also be developed by teachers themselves as suggested in Mugimu and Sekiziyivu (2016).

As regards learner-centred instructions - it was noted that many teachers have misconceptions about this strategy. Teachers are aware that learner-centred instructions are vital to language learning, but, they continue to be key players in classroom instruction. This undermines the acquisition of learners' communicative competences as needed to become effective communicators in real life situations. Yet, in the CLT perspective learners must take responsibility of their own learning by actively being involved in instructional activities and determining the content of the lesson. For instance, learners could be encouraged to engage in free language interaction with peers through the use of pairs and small groups. This could enable them produce language in a way that reflect language use in real-life. Teachers should therefore create realistic contexts of language use, in order to enable learners to select appropriate specific information that is necessary for effective language use in such contexts. While we recognize that teachers of German are aware of the appropriate teaching strategies to support the CLT approach but in some instances, they do not put them to good use due to the unconducive teaching-learning environment as many of them commented. Consequently, if teachers are to teach German using the CLT approach, it is recommended that teacher training institutions emphasize the benefits of this approach especially in terms of promoting language communicative competences in existing contexts. Therefore, teachers must be trained on how to successfully teach using the CLT approach (Ahmad \& Rao, 2013) and also other approaches which encourage learners' communicative use of the language.

\section{REFERENCES}

[1] Ahmad, S., \& Rao, C. (2013). Applying communicative approach in teaching English as a foreign language: a case study of Pakistan. Porta Linguarum, 20(Junio 2013), 187-203.

[2] Butler, Y. G. (2005). Comparative perspectives towards communication activities among elementary school teachers in South Korea, Japan and Taiwan. Language Teaching Research, 9(4), 423-446.

[3] Canale, M. (1983). On some dimensions of language proficiency. In J. J. W. Oller (Ed.), Issues in language testing research. Rowley, Massachussetts: Newbury House.

[4] Canale, M., \& Swain, M. (1980). Theoretical bases of communicative approaches to second language teaching and testing. Applied Linguistics, 1, 1-47.

[5] Coskun, A. (2011). Investigation of the application of communicative language teaching in the English language classrooom - a case study on Teachers' attitudes in Turkey. Journal of Linguistics and Language Teaching, 2(1), 1-23.

[6] Drame, M. (2013). Resistance to communicative language teaching in a foreign language context: a Senegalese case study. http://fastef.ucad.sn/LIEN12/drame.pdf Retrieved on 5th June 2016.

[7] Irvine-Niakaris, C. (1997). Current proficiency testing: a reflection of teaching. FORUM, 35(2), 16-33.

[8] Jin, L., Singh, M., \& Li, L. (2005). Communicative language teaching in China: misconceptions, applications and perceptions. Paper presented at the AARE' 2005 Education Research "Creative Dissent: Constructive Solutions, Parramatta, Australia.

[9] Liao, X. (2011). Communicative language teaching in the Yemeni EFL classroom: embraced or merely lip-serviced? Journal of Langauage Teaching and Research, 2(4), 859-866. 
[10] Littlewood, W. (2014). Communication-oriented language teaching: where are we now? Where do we go from here? Language Teaching, 47(03), 349-362.

[11] Liu, H.-j. (2015). Learner autonomy: the role of motivation in foreigh leanguage learning. Journal of Language Teaching and Research, 6(6), 1165-1174.

[12] Mugimu, C. B., \& Sekiziyivu, S. (2016 ). Authentic instructional materials and communicative language teaching approach of German as foreign language in Uganda. International Journal of Learning, Teaching, and Educational Research, 15(5), 61-74.

[13] Ngoc, K. M., \& Iwashita, N. (2012). A comparision of learner's and teachers' attitudes toward communicative language teaching at two universities in Vietnam. University of Sydney Papers in TESOL, 7, 25-49.

[14] Nunan, D. (1989). Communicative tasks and the language curriculum. TESOL QUARTERLY, 25(2), 279-295.

[15] Nunan, D. (1989) ). Designing Tasks for the Communicative Classroom. Cambridge: Cambridge University Press.

[16] Nunan, D. (1991 ). Communicative Tasks and the Language Curriculum. TESOL QUARTERLY, 25(2), 279-295.

[17] Qamar, M. B. (2016). The impact of learner's autonomy on teaching oral skills (speaking skills) in an EFL classroom. Journal of Langauage Teaching and Research, 7(2), 293-298.

[18] Raissi, R., \& Nor, F. b. M. (2013). Teachers' perceptions and challenges regarding the implementation of communicative language teaching (CLT) in Malasyian Secondary Schools. Paper presented at the Global Summit on Education 2013, Kuala Lumpar.

[19] Richards, J. C., \& Rodgers, T. S. (1987). Approaches and Methods in Language Teaching. Cambridge: Cambridge University Press.

[20] Sato, K., \& Kleinsasser, R. C. (1999). Communicative language teaching (CLT): practical understanding. The Modern Language Journal, 83(4), 494-517.

[21] Sekiziyivu, S., \& Mugimu, C. B. (2015). Relationship between learners' German language communicative abilities and their prior performance in a National Ugandan Certificate Examination. Journal of Language Teaching and Research, 6(1), 43-52.

[22] Snow, D. B. (1996). More than a native speaker: an introduction for volunteers teaching English abroad. Alexandria, VA: TESOL.

[23] Spada, N., \& Frohlich, M. (1995). Communicative orientation of language teaching observation scheme: Coding conventions and applications. Sydney: NCELTR, Macquarie University.

[24] Sreehari, P. (2012). Communicative language teaching: possibilities and problems. English Language Teaching, 5(12), 87-93.

[25] Tomlinson, B. (2012). Materials development for language learning and teaching. Language Teaching, 45(02), 143-179.

[26] Wesche, M. B., \& Skehan, P. (2005). Communicative, Task-based and Content-based Language Instruction. In R. B. Kaplan, W. Grabe \& M. Swain (Eds.), The Oxford Handbook of Applied Linguistics. UK: Oxford University Press.

[27] Widdowson, H. G. (1972). The teaching of English as communication. English Language Journal, 27(1), 15-19.

[28] Widdowson, H. G. (1978). Teaching of English as communication. Oxford: Oxford University Press.

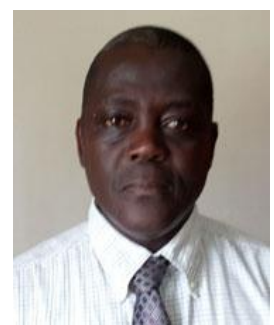

in Uganda.

Samuel Sekiziyivu, earned his PhD in Education from Makerere University Uganda in 2013. His major field of study is Language Teacher Education. He started his professional career as a high school classroom teacher for German language \& Economics from 1988 to 1995, and then as a lecturer in the Department of Language Education, School of Education at Makerere University from 1993 to 1995. His research interest is mainly linguistics, language teacher education and training; language assessment and evaluation. He is currently employed as a German language teacher trainer in the Department of Language Education and Humanities, School of Education, Makerere University and coordinates school practicum at the School of Education. In addition to teacher training, Dr. Sekiziyivu is actively involved in research supervision of graduate students at masters and PhD level. He is also a German language consultant for National Curriculum Development Centre

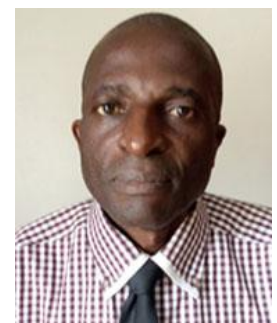

Christopher B Mugimu earned his $\mathrm{PhD}$ in Education with concentration on research in planning, assessment and evaluation from Brigham Young University, Provo, USA in 2004. He is a Professor of Education at Makerere University, College of Education and External Studies. He has more than 16 years of teaching and administrative work in secondary schools and 14 years at university level. His research interests include: Comparative International Development Education, Higher Education, Language of Instruction and Contemporary Curricula Issues i.e. HIV curriculum integration, Assessment of Learning, Teacher Education and ICT provision in higher education. He has published numerous peer referred journal articles and book chapters and has also supervised many masters and PhD students' projects to completion. Dr. Mugimu has also collaborated in joint research projects with colleagues in East Africa, South Africa, United Kingdom and the USA. He has done numerous consultancies in education and curriculum harmonization for the East African Community. 